\title{
TV/Series
}

18 | 2020

Séries et espace

\section{Louisiana and Southern Identities in True Blood (HBO, 2008-2014)}

\section{Mikaël Toulza}

\section{(2) OpenEdition}

\section{Journals}

\section{Electronic version}

URL: http://journals.openedition.org/tvseries/4672

DOI: 10.4000/tvseries.4672

ISSN: 2266-0909

\section{Publisher}

GRIC - Groupe de recherche Identités et Cultures

\section{Electronic reference}

Mikaël Toulza, « Louisiana and Southern Identities in True Blood (HBO, 2008-2014) », TV/Series [Online], 18 | 2020, Online since 15 September 2020, connection on 08 December 2020. URL : http:// journals.openedition.org/tvseries/4672 ; DOI : https://doi.org/10.4000/tvseries.4672

This text was automatically generated on 8 December 2020

\section{(c) (i) (3) $\Theta$}

$T V /$ Series est mis à disposition selon les termes de la licence Creative Commons Attribution - Pas d'Utilisation Commerciale - Pas de Modification 4.0 International 


\title{
Louisiana and Southern Identities in True Blood (HBO, 2008-2014)
}

\author{
Mikaël Toulza
}

\section{Introduction}

1 HBO's True Blood (Alan Ball, 2008-2014), explores a storyworld in which vampires have "come out of the coffin" (S01E01) and live openly among humans; it is mainly set in the fictional rural town of Bon Temps, Louisiana. This town, the name of which could mean either good time or good weather in French, recalls the Cajun expression "Laissez les bons temps rouler" (Let the good times roll) that culturally evokes Louisiana's gaiety. Ironically, Bon Temps is where most of the moments of tension of the series happen. The constant references to Louisiana's segregationist past and conservative present tarnish Bon Temps' name; it is not a place where the characters have a good time. Reallife Southern cityscapes such as New Orleans and Shreveport - the capital of Louisiana from 1863 to 1865 - are also introduced to anchor the series in Louisiana, yet Bon Temps remains the main location in which the narrative unfolds.

2 True Blood's Southern setting is a salient yet complex feature. The inclusion of vampires in this geographically-delimited space alludes to the merging of two worlds, that of the Gothic genre and the American South, in a series that resolutely inscribes itself in the Southern Gothic tradition with its emphasis on the grotesque ${ }^{1}$. In this genre, the threats that could disrupt American identity - especially those dealing with race - are contained in the South ${ }^{2}$. In True Blood, the intertwining of fiction and historical reality results in an emphasis on the differences between humans and vampires along specist lines in the vein of the racial division of the United States. Within this context, the series is set in Louisiana, a region of creolization and intersections ${ }^{3}$ calling for a questioning of Southern identity, often conceived as that of white, working class Southerners. The identities associated with this State, shaped throughout history by French, Spanish, and Anglo-Saxon influences, differ from stereotypical Southernness, yet this Louisianan setting is rarely drawn on in aid of a global and popular South. 
Jason Mittell states that time is the "most central aspect of television narratives." Comparatively, space is a more "consistent narrative element", "the dimension of television narrative that needs the least outside help for viewer comprehension ${ }^{6 "}$; thus he includes space among the orienting paratexts ${ }^{7}$ which are the features of a TV series which help viewers "make sense of complex serial forms through practices of orientation and mapping." Yet, Doreen Massey believes that space "may call to mind the realm of the dead or the chaos of simultaneity and multiplicity9." Spaces and, to a further extent, the identities associated with them, could thus be defined by the interweaving of past and present. In other words, the definition of space has to include both its past and what it has become. Massey further asserts that, because space is not static but in constant evolution, it must be conceptualized integrally with time ${ }^{10}$. History and space should, thereby, be conceived as en cours. Space is, in effect, a social and cultural construct which plays a key part in shaping one's place in the world, thus recalling the naturalist view of the environment as determining one's identity. As Massey puts it,

If, however, the spacial is thought of in the context of space-time as formed out of social interrelations at all scales, then one view of a place is as a particular articulation of those relations, a particular moment in those networks of social relations and understandings ${ }^{11}$.

4 The relation between space and place is an intricate one that could be schematized according to the following equation: space + time = place. It is through time that space becomes place, in other words when individuals show emotional attachment to a specific space and consider it as a place which is, just as time and space themselves, in constant evolution. Thus, given the relationship between space, time, and place, the spaces introduced in the first episodes of a series and in which the characters progress are bound to evolve into places.

5 Massey adds that places are divided into public and private places, ${ }^{12}$ the hegemonic categories being public while the oppressed private. Massey's argument could be extended to other aspects of identity politics. In terms of race, class, and sexuality, it would mean that white, rich and heterosexual discourses are part of the public sphere while others are relegated to the private sphere, or at least to the margins of the public sphere. Nevertheless, minority groups also having public and private spheres within their own power structures, the apprehension of such places is to be intersectional. Intersectionality grasps the dynamic coexistence between individual bodies living different experiences of oppression and the world, ruled by wealthy white heterosexual patriarchs; the subjects' experiences of oppression should be understood according to their personal experiences ${ }^{13}$. David Burley further adds,

In fact, all places are socially constructed in some way. This social construction occurs as place becomes imbued with symbolic meaning according to the values and beliefs embedded in the self-definitions of individuals. These components of identity and their concurrent values and beliefs are, in part, extracted from the larger culture ${ }^{14}$.

Given the relationship between time and space that results in place, it becomes clear that time and space also have an influence on the identities attached to a place. In what follows, I focus on True Blood's most recurring locations - Sookie's (Anna Paquin) house, Bill's (Stephen Moyer) mansion, Merlotte's and Fangtasia - as sites with both dramatic and political potential. These locations can be divided into two sets: one public, one private, each pair belonging either to the human or the vampire world, 
each place having its equivalent in the human or vampire world. All of them are introduced in the series' first season, are of the utmost importance in the final season, and participate in anchoring True Blood in a Southern context. Because True Blood's seven-year run induces developments in the politics associated with both the places and the characters, the first and last on-screen appearances of each place will serve as bases to get a grasp of the evolution of the series' politics and serve as a basis for this analysis. The order in which the places are introduced draws a line from the most human of places to the most vampiric one. Merlotte's is the first landmark introduced (S01E01), followed by the Stackhouses' house (S01E01). Then, when Sookie and Bill get closer, she walks him home (S01E02). Logically, the most vampiric recurring place, Fangtasia, is the last one to be introduced (S01E04). Like Lost (ABC, 2004-2010) in Mittel's analysis, True Blood's last season returns to the most emblematic people and past places ${ }^{15}$ and its finale concludes "with a going away party ${ }^{16}$." These places appear as synecdoches for the United States and participate in True Blood's seriality by bringing back viewers to recognizable locations where identities are played out and potentially subverted.

\section{Setting the Series in the South}

7 In the pilot's opening sequence [S01E01, 00:06-03:58], a white heterosexual couple is driving on an endless dark road at night. The characters' strong Southern accents, the road framed by trees draped with Spanish moss, and the country music playing on the car's radio set the action in the South. The woman is driving while her boyfriend is asleep. She wakes him up with a hand-job, suggesting the couple - and viewers - are entering a sexually charged story world. Then, they stop at a market, GrabItKwik, that sells Tru Blood, a drink that allows vampires to get sustenance without harming humans.

GrabItKwik, the name of which recalls famous by-the-road market chains such as Kwik Trip, is shown in an establishing shot of its frontage. It is quickly followed by an interior close up of a mirror hanging from one of its ceiling's corners, framed with boxes of Bud Light and Amstel Light, two popular American beer brands (Fig.1). 
Figure 1: Close shot of a mirror hanging from GrabltKwik's ceiling [S01E01, 00:58]

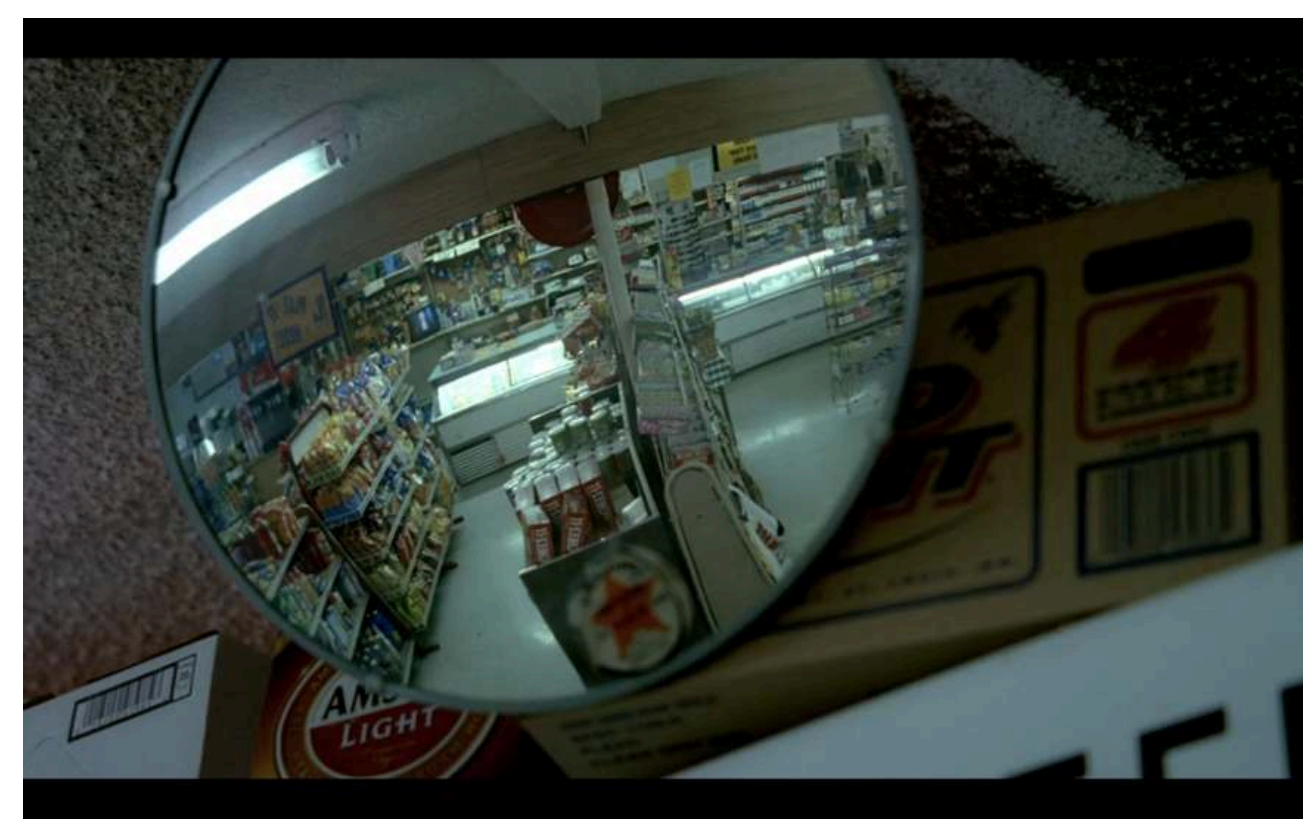

In the reflection, stacked boxes of Cheez It as well as popcorn bags, chips bags, and refrigerators can be seen. Because it looks like the interior of any other market, GrabItKwik could stand for some sort of Anywhere, America - a microcosm that stands for the entire country. The narration cuts to a close shot of a TV confirms this idea. Both the viewers and the cashier get to see Nan Flanagan, head of the American Vampire League (a group of political activists asking for equal rights for vampires), talk about the global situation in which the series is set. Vampires are living among humans and, thanks to the Japanese, can feed in non-lethal way. A skeptical male TV anchor asks Flanagan about the dangers of giving vampires equal rights. Her answers are filled with parallels to slavery that call to mind the US' racial history, vampires being overtly compared to African Americans. The narration zooms out from the TV and introduces the market cashier, connecting the global to the local.

GrabItKwik's cashier is introduced through a long pan shot of his clothes, tattoos and jewels. He is wearing rings ornamented with Satanic symbols, a bracelet made of bullets, black clothes, and has long black hair and pale, almost translucent white skin. His style aligns him with the Goth stereotype, all the more so as he first speaks with an Eastern European accent that calls to mind the association of vampires with Transylvania. The couple comes in and asks the cashier about both Tru Blood and the situation of vampires in Louisiana. Relying on his appearance and the popular association of vampires with Goth culture, the cashier easily makes them - and the viewers - believe he is a vampire. He eventually admits it was a joke, thus revealing the deceptiveness of performed identity. He is, in effect, just another privileged white male who appropriates discourses that do not apply to him and passes for what he is not - a figure of otherness. Relieved, the couple asks if they could find some " $\mathrm{V}$ juice" vampire blood is used as a drug by humans. During the conversation, the man keeps punctuating his sentences with "dude" and the woman refers to the use of vampire blood by her fellow sorority members during a Greek party. Not only are they a white couple, but they are also aligned with the frat boy and sorority girl stereotypes, thus embodying white upper-middle-class/upper-class elite. 
Before the couple comes in, someone is heard whistling in the store. The narration reveals a man wearing camouflage clothes and a cap with the Confederate flag on it. Framed by the interior of the refrigerators with beers in the foreground, he appears to be a typical redneck looking for a drink. When the college students ask for vampire blood, though, the redneck customer stops the conversation and asks them to leave. The frat boy relegates him to the rank of "Billy Bob," an expression used to refer to rednecks. In so doing, the frat boy relies on the customer's clothing to align him with this stereotype. However, this unnamed Southerner reveals that he is a vampire, scares the couple away and warns the cashier about incarnating an identity that is not his.

Figure 2: Medium shot of the frat boy and the sorority girl (foreground) and the cashier (background) [S01E01, 03:18]

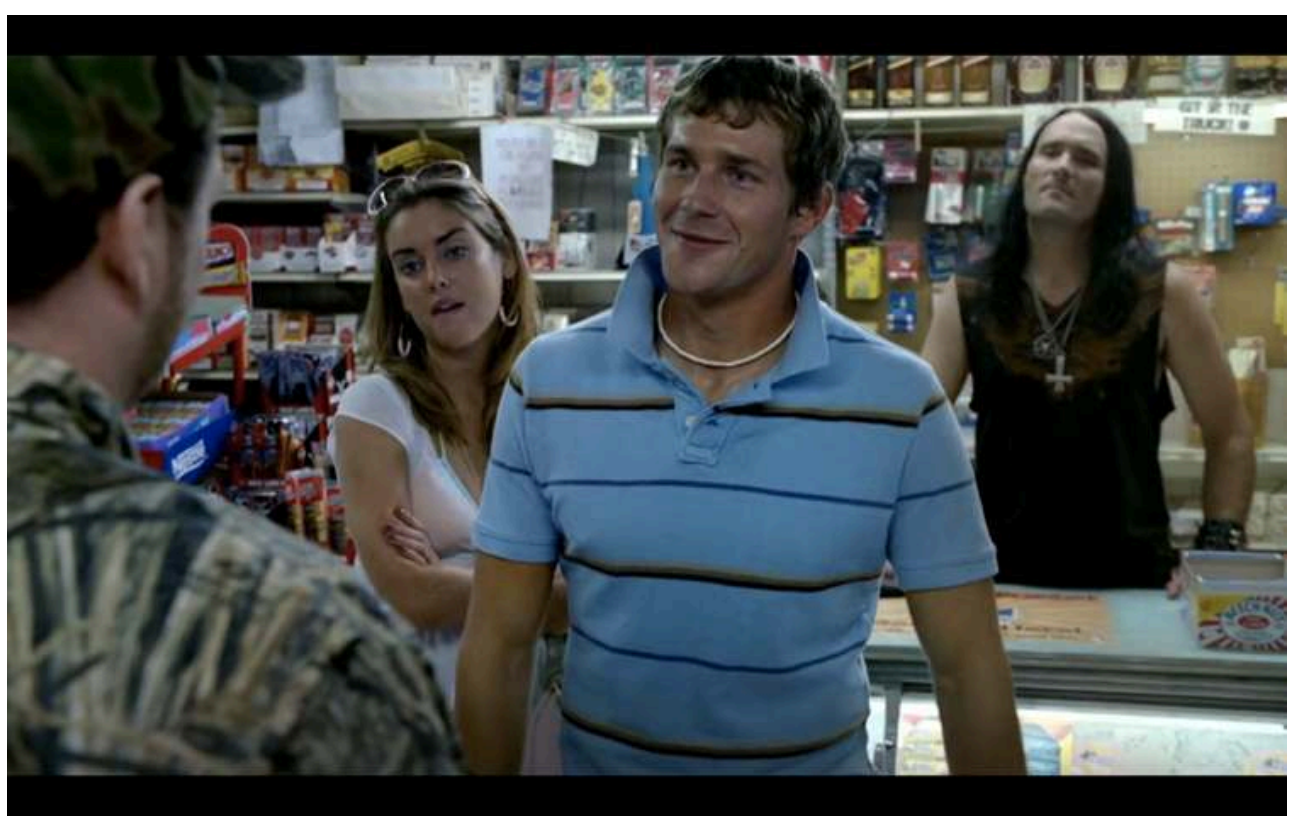

Figure 3: Medium shot of the redneck vampire customer [S01E01, 03:29]

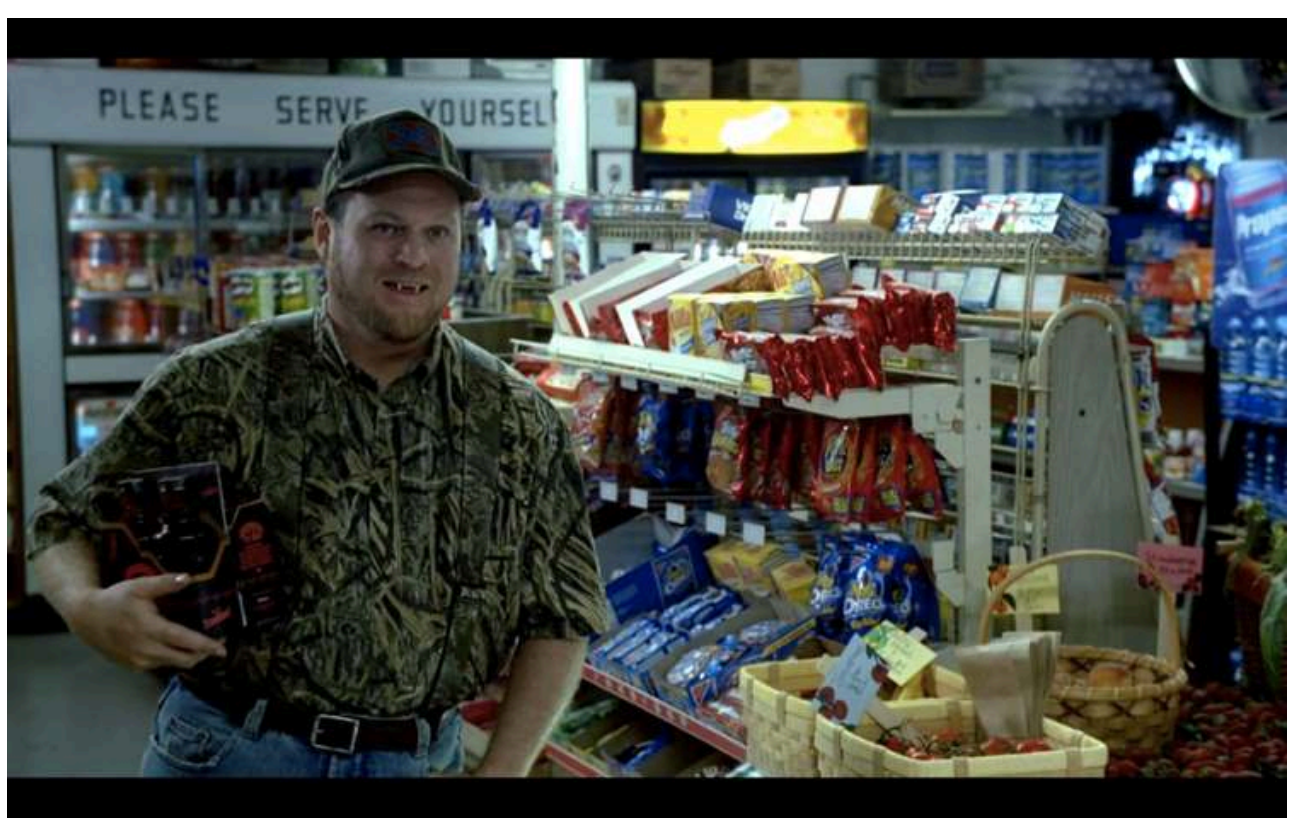


12 Not only does the first sequence set the series in the South and show its relevance to American society, but it also reveals the deceptiveness of stereotypical identities. Relying on two subverted stereotypes induced by the location and global context of the series - the redneck and the vampire - and confronting them to rich white characters, this scene sets the tone for the series' subversive potential and exposes identities as social constructs and disguises. It evokes a construction of the Southern back country as being where the gender, sexual, regional and class tensions are presented as high dramatic stakes. In the Southern Gothic tradition, the South is clearly a troubled and troubling space. The exploitation of this genre thus foregrounds identity tensions. In True Blood, these tensions are specist and sexual-the most frequent figures of otherness in the series are vampires and homosexuals. This combination of traditional Southernness and vampires points to the tension between hegemonic and nonnormative discourses, suggesting that True Blood ambitions to complexify and potentially subvert them. Yet Sabrina Boyer contends "[d]espite the thoughtful use of the vampire archetype to explore notions of difference and otherness surrounding race and sexuality, the True Blood series ultimately fails to redefine, disrupt, and upset the historical racist, sexist and homophobic ideologies of the South ${ }^{17}$." Boyer believes that one of True Blood's shortcomings lies in its non-re-assessment of Southern ideologies. Yet the on-screen portrayals of such ideologies is due to the series' Louisianan setting. This particular space leads to a reflection on the form of social conservatism often associated with the South and allows the series to confront it with figures of otherness. So what if the point of True Blood were not to redefine, disrupt and upset the ideologies of the South but to portray the South as more diverse than it is stereotypically believed to be? True Blood's progressive potential does not necessarily lay in an attempted redefinition of the South, but in its envisioning of stereotypical Southern identity as just as layered as individual identities.

\section{Having a Good Time at Merlotte's}

The town of Bon Temps, in the back country, is constructed as a traditional and conservative locus. Social life in Bon Temps mainly revolves around Merlotte's Bar and Grill, a stereotypical swamp bar whose owner lives in a trailer and thus conforms to the stereotype of Southern white trash. In the pilot episode, a great amount of time is spent at Merlotte's; it is the location where all the characters get together. Merlotte's is introduced even before the main characters. The first sequence there opens with a pan following a car driving towards Merlotte's at night. It eventually makes way for a long shot of the bar and grill (Fig.4), in which the foreground is completely black, while the background, hidden behind the trees, is lit by the restaurant's neon light sign, the streetlamp, but also by a light from above, probably that of the moon. The composition of the long shot constructs Merlotte's as the metaphorical light at the end of the tunnel, the only escape from the back country's darkness. 
Figure 4: First shot of Merlotte's. S01E01 [05:34]

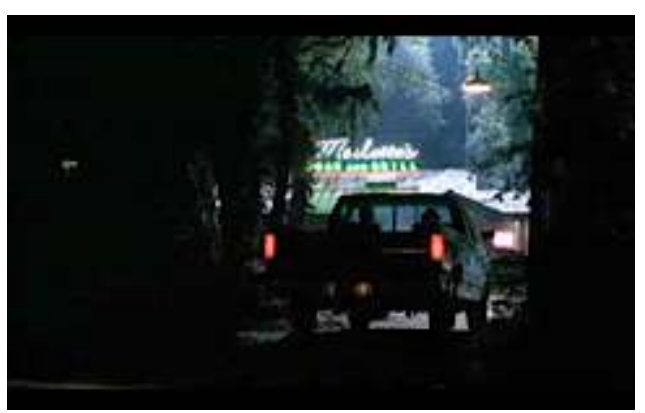

14 Merlotte's interior is revealed through a long tracking shot of Sookie waitressing [S01E01, 05:28-06:53] interspersed with close ups of her and the customers' faces. Sookie being clairvoyant, she can see through the customers' social disguises and hear their personal thoughts. These thoughts allow the viewers to get a glimpse at Merlotte's structure and varied clientele. The first thought is that of a man, praying God to help him resist alcohol [05:48-05:55]. In a nod to Evangelists and the reputation of the South as the Bible Belt, this customer constructs Merlotte's as home to a conservative clientele. Then, a woman internally criticizes her husband for making a remark about her eating French fries. She adds that he should not make such remarks, "not after what [she] did to [him the night before] in the bedroom, which by the way was disgusting although [she] kinda enjoyed it" [S01E01, 05:57-06:06]. Such a thought exposes the tension between the private and public spheres, inherent to the drama genre, but also foreshadows a deconstruction of toxic behaviors, particularly in terms of gender; in this case the fact that women's physical appearance and behavior in the public sphere could be dictated by men. Finally, Sookie hears the thoughts of a teenager [06:09-06:42] who feels trapped in a "hillbilly's OxyContin nightmare" and "can't wait to get out of this Podunk town," expressing how unpleasant it is for him to live in this region. Sookie answers and he wonders if he were speaking out loud, also thinking that he should "get rid of [his] magazines" because his parents would kick him out of the house if they found them, juxtaposed with his mother thinking "does he have a girlfriend?" This teenager is constructed as a young gay man in the closet. The confrontation between stereotypical Southernness and figures of otherness is, thus, inevitable in this place. The shot/reverse shot technique used during this exchange accentuates the customers' reactions to Sookie's mind-reading ability, which associates white, working-class femininity with otherness. Her ability exposes the hypocritical stance of these characters in keeping with popular notions of Puritanism and plays on contrasts between visual appearances and inner life, between the inside and the outside, but also between image and sound. Merlotte's is imbued with a Fantastic element, here Sookie's power. As such, it is a place where appearances are bound to be unraveled.

Merlotte's social structure is paralleled by its owner and employees' occupation of this confined space. The introduction to Merlotte's ends with a shot of its white male owner, Sam Merlotte (Sam Trammell), standing behind the counter. The counter and the office function as gender, race and class boundaries, Sam, being the character who, because of his status and the later-exposed fact that he is a shape-shifter, can cross them with ease. True Blood quickly reveals that Merlotte's is a place where hegemonic discourses are meant to collide with powerful figures of otherness. From the second half of the pilot episode on, Tara Thornton (Rutina Wesley) becomes a waitress at 
Merlotte's and challenges Sam's authority (S01E01). Unlike most of those who work there, Tara imposes her presence behind the counter, which eventually leads Lafayette (Nelsan Ellis), Tara's black gay male cousin with androgynous features and clothes, to occupy this space as well, hence openly displaying forms of racial and sexual otherness to the conservative white Southern clientele. Such confrontations occur in response to the customers' grotesque display of hegemonic behaviors. In the first season, Lafayette is mostly in the kitchen, as if Merlotte's were meant for those who do not fit in a white patriarchal discourse to remain in limited spaces. The kitchen functions as a symbolic space which contains Lafayette's sexual ambiguity. In the "burger with AIDS" scene [S01E05, 34:16-36:13], during which Lafayette' sexual otherness confronts two rednecks' conservative ideas and ideals. This scene is divided into two parts. First, Lafayette is in the kitchen, combining various signifiers of traditional masculinity, femininity, and blackness (Fig. 5); on the one hand, he is wearing a skin-tight tank top showing his muscles and an African headscarf that can be envisioned as a nod to Gangster culture; on the other, his headscarf, earrings, golden bracelet, and make-up, imbue him with black feminine characteristics.

Figure 5: Lafayette in the kitchen, S01E05 [34:17]

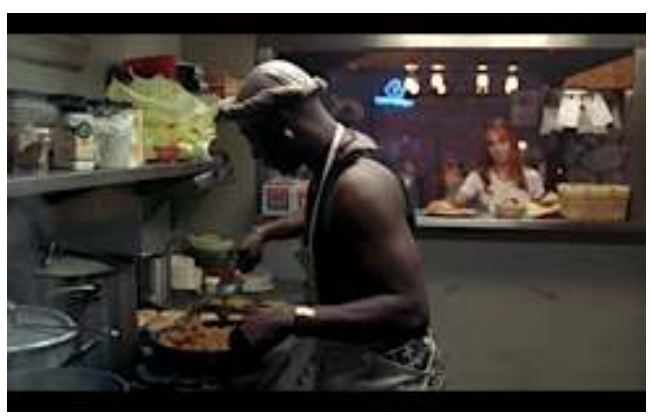

Arlene (Carrie Preston), one of the waitresses, tells Lafayette that some customers do not want to eat the burgers he made because they "might have AIDS" [S01E05, 34:38]. An angry Lafayette then rushes out of the kitchen to confront these customers who define him by his sexual orientation, which they denigrate. Lafayette's first reaction is to take off his earrings. Symbolically, it means that he is momentarily getting rid of his performed feminine side to adopt more traditional masculine characteristics. His physical coming out of the kitchen parallels his psychologically coming out of his comfort zone. Lafayette's performance of gender, race and sexuality is appreciated by the customers when contained in the kitchen, but becomes threatening when he steps outside that zone. Samuel Chambers writes that the performance of a coming out creates one of the rare moments during which a heterosexual person feels the tensions of the closet because the presumption of heterosexuality no longer holds ${ }^{18}$. This tension is felt during the confrontation between Lafayette and the customers, which happens in Merlotte's dining room, the customers' comfort zone.

The room is thus constructed as a theatrical space in which stereotypical identities are performed. Here, Lafayette takes on the stereotypical role of the "over-sexed and savage ${ }^{19}$ " black buck who openly says he has sex with a lot of men around Bon Temps who would not admit it. Hence, he could be contained behind the counter because his coming out into the open space causes the repressed desires of those in the closet to come out. It is not Lafayette who comes out; rather, he acts as a catalyst for the coming 
out of those who are supposed to embody a hegemonic form of Southernness. Merlotte's imbues Lafayette, just like Sookie, with the ability to unravel others. The similarity between these characters' abilities draws a parallel between supernatural powers and non-normative sexuality. One of the customers states "I am an American" [35:24], implicitly suggesting that Lafayette is a figure of otherness for this white patriarch even though is name is a reminder of the importance of otherness, here a Frenchman, in the construction of American nation. When Lafayette replies "Faggots been breeding your cows, raising your chickens, brewing your beer long before I walked my sexy ass up in this motherfucker" [35:28-35:35], he outs the chicken and beef raising industries as well as breweries, all three of them being cherished by his redneck customers. Lafayette suggests that many other industries are controlled by homosexuals, exposing the presence of multiple pervasive figures of otherness within the small town and the nation throughout history and cultural history. In other words, the varieties of otherness (racial, sexual, social, etc.) tied to Merlotte's is inscribed in history and is instated as the sociohistorical reality, thus debunking the stereotypical Southern identity. The altercation is filmed in shot/reverse shot, with Lafayette in low angle and the redneck customers in high angle, as if the narrative were reproducing both the oral fencing between the characters and Lafayette's superiority within Merlotte's. Not only are normative identities and behaviors confronted to a hybrid figure of otherness, but this altercation is a step towards otherness gradually becoming the norm in this place thanks to the serial format confronting normativity and otherness on a regular basis. Lafayette's performance combining stereotypical black masculine and feminine features shows that he can confront and subvert the customers' whiteness and heteronormativity. The spatial change allows Lafayette to reframe his performed identity to adapt to his customers' discourse. At the end of season six, Sam offers his restaurant as a wedding gift to Arlene, whose last name is now Bellefleur. The place that was once owned by a male figure of otherness becomes a woman's property. Merlotte's becomes Bellefleur's and is in the hands of a character who has gone from working-class waitress to being aligned with a business-owning Southern Belle. In other words, Arlene's character arc led her to climb the Southern social ladder. With this character, Southern identity is preserved, even sublimated, and Americanized.

19 The last time the viewers see Bellefleur's [S07E09, 19:45-22:47], a sad Sookie has retreated there because she just learned she had contaminated Bill with Hep-V; a lethal disease for vampires which, just like AIDS, is transmitted through blood and sex. The restaurant's main room is divided into two spaces. On the one hand, recurring characters such as Arlene, Andy Bellefleur, and Lafayette are having a meal around the table. They are supposed to look like random customers to attract those who have deserted this place after all the events and deaths that happened there throughout the seasons. On the other, Sookie is on her own at the counter. Adilyn (Bailey Noble), Sheriff Andy Bellefleur's (Chris Bauer) faerie daughter, has a telepathic exchange with Sookie to ask her if she is well. This is when Arlene crosses the boundary that separates Sookie from the group to lift her spirits, thus materializing the intertwining of public and private tensions that occur in this place and paralleling it with Arlene's displacement from the group to Sookie. At the counter, the two women talk about being in a relationship with a vampire. Arlene, who was so prejudiced against vampires at the beginning of the series, is dating one. The series proposes a realignment of this character to sociological reality by showing that even the most conservative version of 
the Belle can evolve, thus suggesting that even the most conservative people in the U.S. could accept progress.

Unlike in the first scene in this place, it is not hegemonic discourses that mostly populate Bellefleur's but figures of otherness. It is filled with fairies, vampires, AfricanAmericans, brujos, homosexuals, as well as with characters such as Andy and Arlene who, even though they still incarnate stereotypical Southernness and humanity, have become more accepting in contact with figures of otherness. Merlotte's, then Bellefleur's, is thus much more than the stereotypical Southern bar. Beyond the surface, it is a place where normative identities and behaviors are confronted to figures of otherness. With its transformative potential, perhaps this place really is the light at the end of the tunnel.

\section{Big City Fangtasies}

21 Merlotte's and the vampire bar Fangtasia, a stereotypical urban Gothic nightclub, may have an entirely different clientele, yet the series immediately establishes their common denominators: these closed spaces have, for some characters at least, porous boundaries. Merlotte's welcomes vampire customers and Fangtasia human ones. Both public places are sites in which normative and non-normative behaviors compete and are contained, thereby undercutting a superficial dichotomy between the urban liberalism of Fangtasia and the reactionary politics of Merlotte's. Located in Shreveport, one of Louisiana's border towns with Texas, Fangtasia functions, in effect, as Merlotte's vampiric doppelgänger. The Bon Temps characters' visits to Shreveport reveals their desire for forms of sexual fantasies they have never encountered before. This is especially true for Sookie, who is still a virgin when she first enters the stereotypical urban Gothic nightclub Fangtasia in S01E04 [S01E04, 30:08-34:09]. Contrary to the establishing shot of Merlotte's, the two shots that introduce Fangtasiathe medium shot of Fangtasia's entrance (Fig. 6.1) is followed by a long shot of the premises (Fig. 6.2) - are plunged in darkness; here, it is the parking lot which is in the light, thus highlighting the apparent opposition between these two bars.

Figure 6.1: Medium shot of Fangtasia's entrance. S01E04, [30:08-30:10]

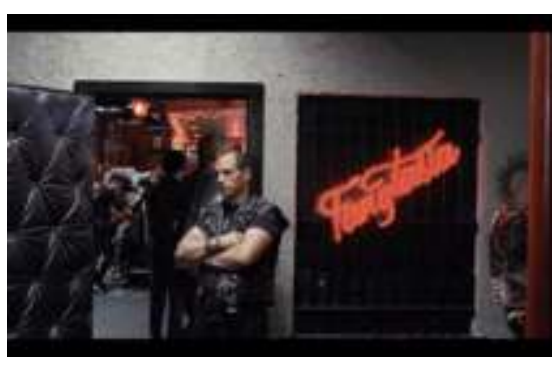


Figure 6.2: Long shot of the entrance and part of the parking lot. S01E04, [30:10-30:12]

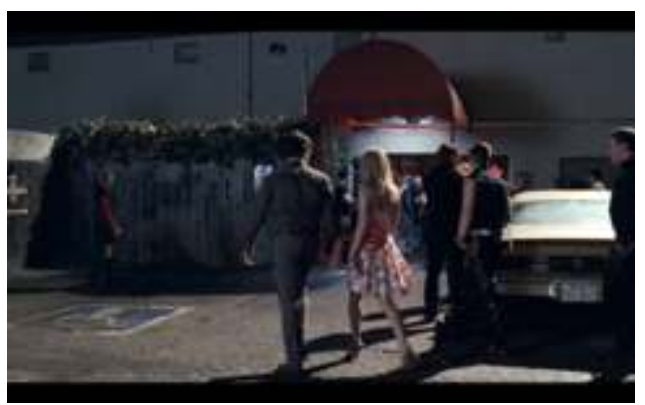

The first medium shot of Fangtasia's entrance (Fig 6.1), divided into three frames, presents the vampire bar as a layered. The first frame, on the right, is delimited by the closed shutter on which a neon sign with the name of the bar hangs. The contrast between the shutter's darkness and the red neon suggests that Fangtasia is a tacky place. Behind its regular, even seedy, façade (Fig. 6.2), it draws one's attention with the promise of a special experience. The leather door on the left, which constitutes the second frame, is characterized by its main use. It is supposed to be sound-proof, thereby showing that Fangtasia is a place with the ability to contain noise and behaviors the outside world is not fully ready to accept nor embrace. The last frame is a glimpse of what lies beyond the entrance. The combination of the skeleton hanging in the top left corner, the security guard in the foreground, the customers wearing black leather in the background, and the dim red lights of both the neon sign and the interior of the bar conjures up a sadomasochistic and hypersexualized atmosphere. The cradle of otherness that Fangtasia incarnates associates sexual fantasies and danger, as its name indicates, and contains them. In this scene, it reflects Sookie's personal apprehension of having sexual intercourse for the first time.

Subsequently, a series of long shots constructs the viewers' apprehension of space within the bar. One of them shows Eric Northman (Alexander Skarsgård) on his throne in the middle of the stage [S01E04, 33:08]; it is followed by a medium close-up of his legs and the camera tilts up to his face. The narration visually constructs Eric as a deity, even more so as Sookie overhears a human male marveling at how beautiful and attractive he is. The human is then shown kissing Eric's foot as if he were bowing to his king. In this scene, close-ups of both male and female dancers wiggling on catwalks suggests that objectification knows no gender. The combination of these catwalks and the main stage create a theatrical space within the vampire nightclub. The characters are performing on these stages as much as the actors who portray them perform in front of the camera, revealing these cliché identities as performances. This mise en abyme emphasizes how stereotypical the roles they incarnate are, as well as those of their clients. In this scene, the main figure of visual pleasure is not the nude vampire but the powerful Eric whose body is fetishized through costume and lighting. The vampire other, in this case a white male, performs onstage. This performance is induced by the place in which it is set. Being a bar, Fangtasia has to appeal to customers for them to come in and consume. As such, it draws on the sensationalistic images attributed to vampires the customers would like to come across with. Eric's sexualization on the bar's stage is a way for him to thrive financially, thus underlining the similarity between human and vampire power structures. In this case, the place the action is set in heavily influences the characters' behaviors. 
"This feels a little bit like what a vampire bar would look like if it were a A ride at Disney World," [S01E04, 31:11-31:17] Sookie tells Bill after she sees two human customers purchasing souvenirs. Even though it glorifies sex and queerness, the vampire bar also makes them legal all by integrating them into a capitalist structure, here in a visual echo to theme-based restaurants in the US such as Hard Rock Café and Planet Hollywood. The first character introduced upon Sookie and Bill's is Pam (Kristin Baueur Van Straten), a tall blonde vampire woman wearing black clothing and jewelry that imbue her with dominatrix characteristics (Fig.7), reinforced by her cold and condescending tone when she talks to Sookie and Bill.

Figure 7: First shot of Pam in Fangtasia [S01E04, 30:28]

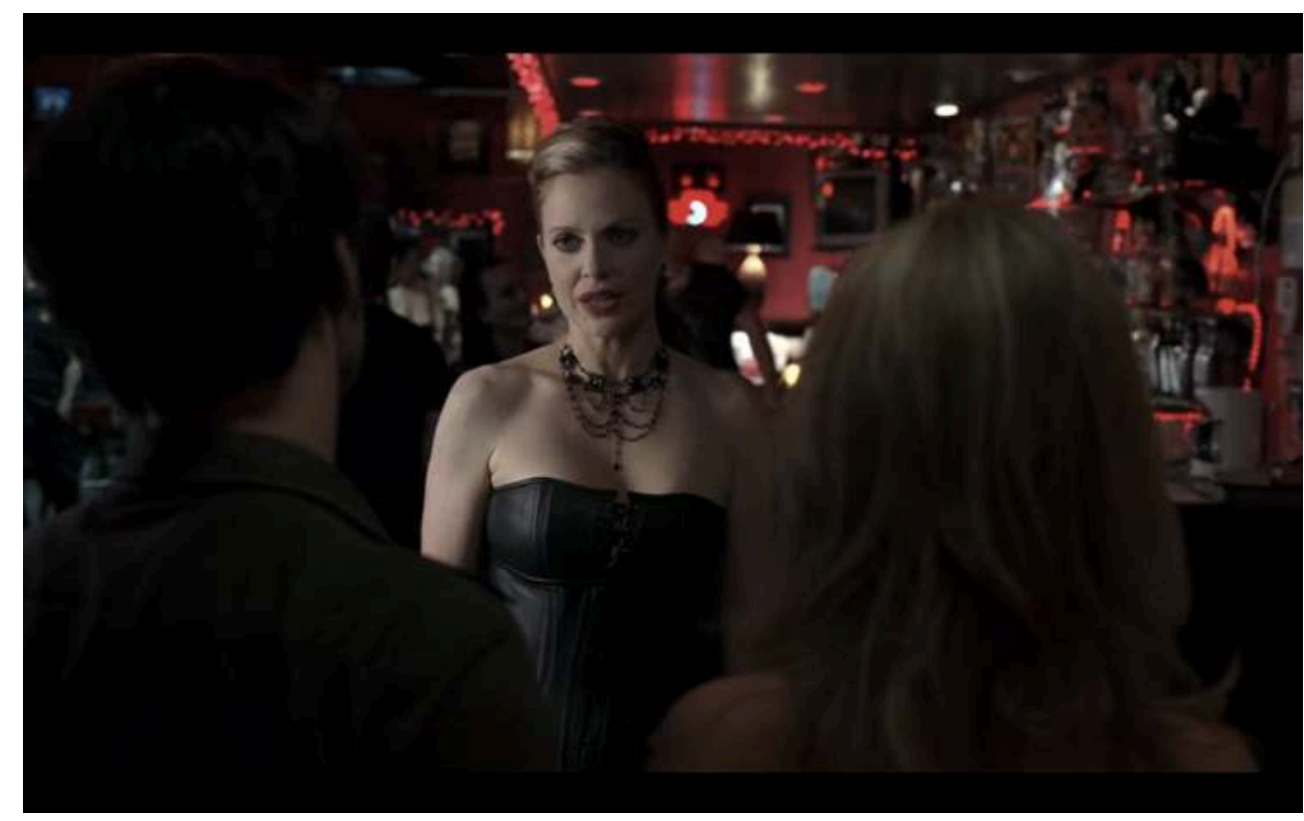

Combined with the shots of the customers wearing black leather clothes, the way Pam is shown exacerbates the sadomasochistic Goth atmosphere and recalls the way the cashier at GrabItKwik performed vampire identity. However, whereas the cashier was a usurper appropriating another group's characteristics, Pam is a vampire who these characteristics. Yet the cashier was punished for it, meaning GrabltKwik and vampire identity are not meant to collide while Fangtasia is propitious to such a performance. In both cases, though, their performance of vampire identity is rooted in their customers' apprehension and desires. Fangtasia's employees replay hegemonic discourses and stereotypes associated with vampires in an excessive way. The vampires re-appropriate these stereotypes to capitalist ends, thus commodifying both vampire identity and sexuality.

Behind the apparent liberalism and promotion of otherness played out it its main room, Fangtasia hides violence. At the end of the first sequence there, the man who was attracted to Eric touches his leg and is kicked away, hits his head against a table and starts bleeding. He is instantaneously surrounded by vampires, among which a woman who introduces herself and makes him leave with her. The change of atmosphere, which switches from amusement to danger, is strengthened by the metalcore tune "Demon(s)" (2007) by Darkest Hour playing in the nightclub, the soundtrack relying on the association of this music genre with brutality. Fangtasia's explicit violence does not 
occur in its main room, since it could scare customers away, but behind closed doors, especially in its basement, where Southern history is blatantly replayed. Holding Lafayette captive in Fangtasia's basement in the series' second installment, Eric and Pam re-enact slavery. Because vampires metaphorically stand for minority groups in the True Blood universe, this arc could be seen as blurring the series' politics. Yet it aligns Eric and Pam, standing for a liberal elite, with slave-owners and, to a further extent, with white supremacists. Drawing on the similarities between the two ends of the political spectrum, Fangtasia reveals the repressed desires of white supremacists, like those humiliated by Lafayette in Merlotte's in S01E05, who would like to inflict this punishment on the black homosexual. The club is thus imbued with the power to tone down political differences and show how absurd extremism can be on both sides, especially since the basement in which the re-enactment of slavery occurs is the last part of Fangtasia the viewers get to see. After Sookie kills Bill in the series finale, a year time ellipsis jumps to Pam and Eric's commercializing New Blood, a cure for Hep-V made from Sarah Newlin's blood. Sarah Newlin is a highly conservative and televangelist woman whose goal throughout the series was to eradicate vampires. When a cure was found for Hep-V, she consumed the only antidote ever made, meaning that her blood became the only cure against the disease. A second time ellipsis, this time of three years, shows Eric and Pam registering their company to the New York Stock Exchange, making the most out of the capitalization of their product. Finally, a last time ellipsis to the next Thanksgiving allows the viewers to say goodbye to Fangtasia [S07E10, 59:58-1:01:56].

Figure 8: Last scene in Fangtasia's basement [S07E10, 1:00:33]

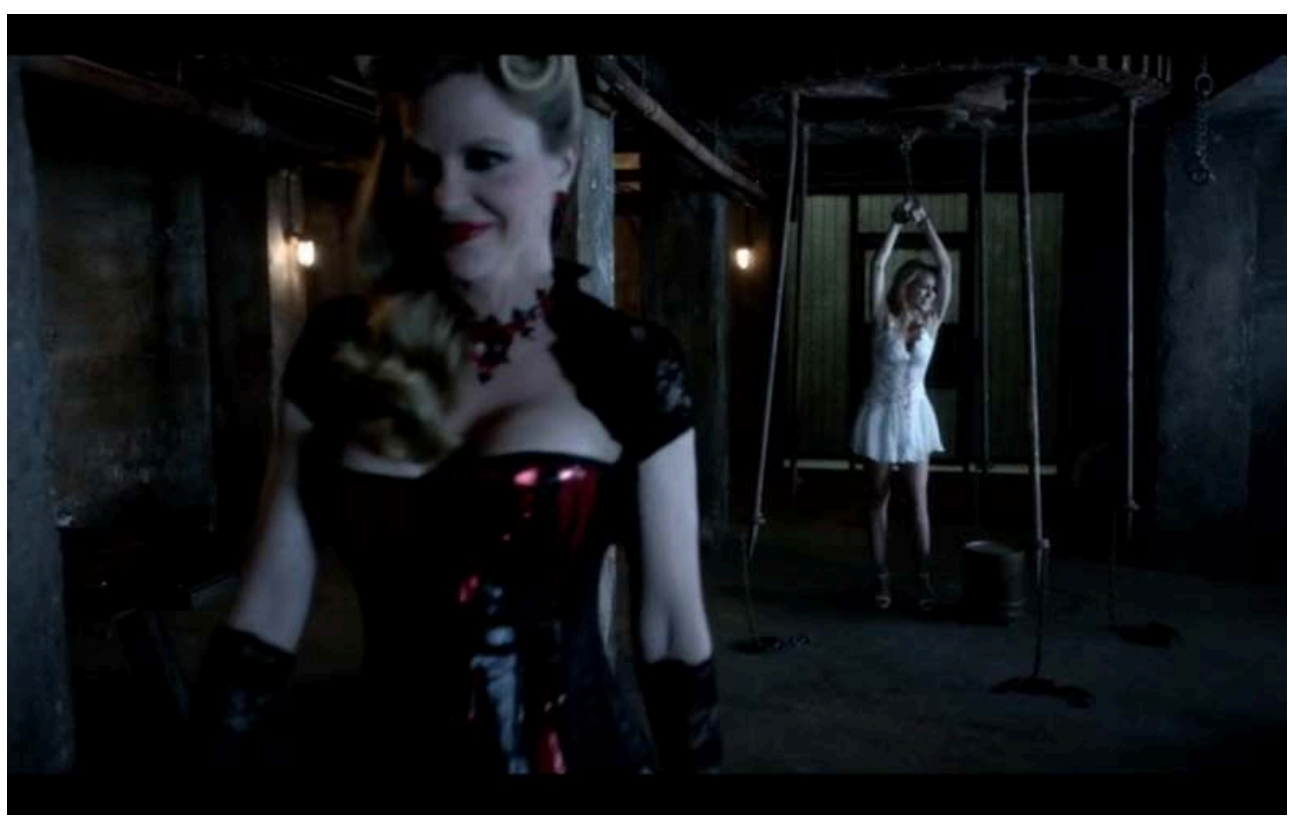

While Eric resumes the position he had in his first on-screen appearance on his onstage throne, Pam is in the basement. Fig $n^{\circ} 8$ shows that her outfit is an upgraded version of the one she was wearing the first time she appeared onscreen. In the background, Sarah Newlin is held captive in chains and vampires can feed off her for a minute for $\$ 100.000$. The capitalist vampires thus replay slavery in the name of capitalism, as good descendants of Bram Stocker's Dracula who invested in real estate in London. Given the association between vampires and figures of sexual otherness throughout the series, 
Pam and Eric's use of Sarah is also a form of sexual slavery. In the course of the series, Pam's past as a brothel madam is developed. She returns to her origins and she and Eric replay their first appearance onscreen, which suggests that these vampires cannot evolve because they are bound to reassert capitalism. Ironically, vampires enslaving humans is exactly what the TV anchored feared in the opening sequence of S01E01. Sarah Newlin, a former liberal advocate for equal rights for vampires, turned more conservative and joined the Fellowship of the Sun church after her sister disappeared, supposedly taken by vampires. Because she wears a white dress, a symbol of purity in Christian faith and is a wealthy, heterosexual, white woman, Sarah is constructed as a stereotypical version of the Southern Belle. Here, the Belle is also a born-again Christian who voices her strong anti-vampire stance throughout the series. Her being enslaved in the finale is a reinterpretation of history that strikes back at conservative southerners for appropriating the Belle, a mythical character in Southern cultural history who lived in plantation houses, thus who took part in enforcing slavery. On the other hand, it also exposes the extremism of some liberals who feel the need to punish socially conservative people in order to prove them wrong.

Fangtasia is a place where the capitalist liberal elite replays the abject Southern past. Eric's last name, Northman, takes on a whole new meaning. Even though it encapsulates his Viking origins, this last name that literally means "man of the North" also associates him with the white liberal northeastern elite resented in Southern history. Eric being tall, fair-haired and white-skinned, he symbolically also stands for the Aryan god that calls to mind the atrocities of WWII and the idea of racial, here specist, domination. The confrontation between Eric and Bill over Sookie could thus be re-interpreted as a romantic re-performance of the Civil War, the female protagonist standing for the whole country. In the end though, Sookie lets go of both Eric and Bill, suggesting that the country should let go of its political and geographical divisions to be united again. Fangtasia's function as a synecdoche for the US lies in its display of open-mindedness and inclusion of minorities while the dark secrets that lie in its basement are muted. A form of slavery ends up being at the service of capitalism and specist domination. This place exposes the contradiction between True Blood's apparent progressive stance, shown through the obvious integration of figures of otherness, and the re-performance of social conservatism by these same figures of otherness, who replay and enforce hegemonic behaviors within their non-hegemonic power structures. It is in this middle-ground to be found between tradition and progress that the series' private places are also anchored.

\section{The Stacked Stackhouses' House}

While most of the places and locations introduced in the True Blood story world are shown in an establishing long shot before the characters walk in. This is not the case of Sookie's house [S01E01, 32:48-33:06], the only place in which the viewers are brought without seeing it from the outside, which suggests a focus on private matters more than on public ones in this place. The first shot of the Stackhouses' is a medium close up of moths on a mosquito net certainly evoking the South in the foreground while Sookie is walking in in the background. It then pans to the kitchen window through which the viewers see Sookie and her grandmother, Adele Stackhouse (Fig.9). 
Figure 9: Sookie framed within the window's frame [S01E01, 33:05]

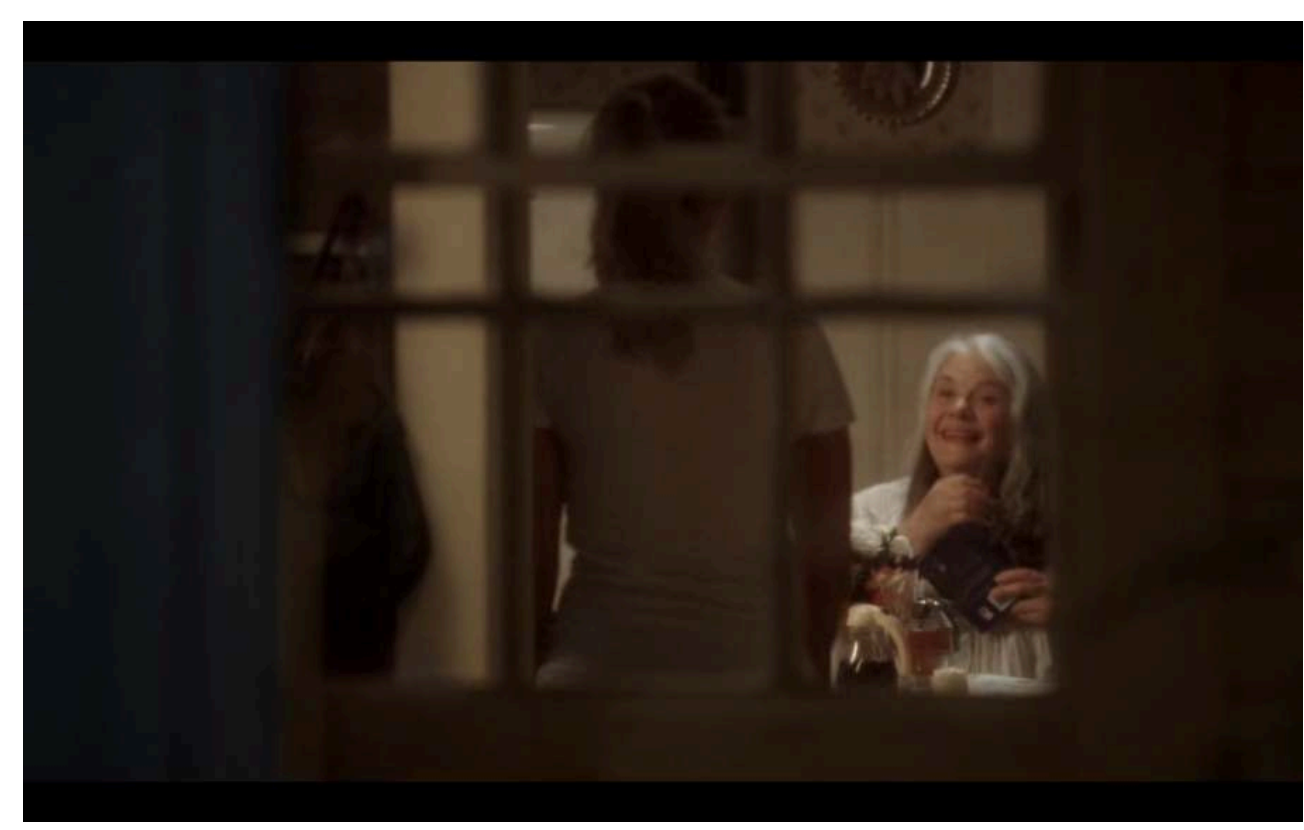

The externality of the viewers and the framing of these characters within the frame physically display the house's protective characteristic for Sookie. In this safe environment, Sookie tells her grandmother, Adele (Lois Smith), about meeting Bill. Unlike other humans from Bon Temps, she suggests that her granddaughter could be romantically attracted to the vampire. In a way, then, Adele is more liberal than conservative, which contrasts with her participation in the Glorious Dead Society, an association that pays tribute to the soldiers who fought for the Confederacy during the Civil War. This characters' politics are imbued in the Stackhouses'. A synecdoche for the South, this place alludes to the convergence of tradition and progress. The more personal Adele's questions get, the closer the shots of the characters' faces. Sookie's state of mind is revealed through her grandmother's behavior. The protagonist is presented as a girl who still needs protection from an older family member. Sookie's house is thus a place where private conversations take the lead. Mostly shown in a sunny context, the Stackhouses' frames Sookie as a contemporary version of the blonde Southern Belle, and appears as a fundamentally white, heterosexual and feminine place.

Upon Adele's murder, the Stackhouses' becomes the place in which Sookie is gradually reborn as a woman. The house finds a way to be reborn without any fertile sexual intercourse, meaning this rebirth can be considered a form of parthenogenesis. The myth of the archaic mother, studied by Creed in her analysis of Aliens (Cameron, 1986) thus underlies the narrative. Creed states that the queen alien is "the point of origin and of end" ${ }^{20}$ and adds that "she is there in [...] the womb-like imagery" ${ }^{21}$ Similarly in True Blood, Fig.9 displays Sookie's entrapment in her house and suggests that the Stackhouses' can be envisioned as a physical representation of the protective womb Sookie is growing up in. Yet, it also a lethal space, in which the power play between the characters leads to the death of at least one of them in every season of the series. It is partly thanks to these murders that Sookie grows. The house thus posits murder as a source of renewal and evolution.

The house's first appearance makes Sookie's internal thoughts come out. The protagonist has her first erotic dream about Bill [S01E01, 33:06-34:21]. Wearing pink 
and white pajamas, Sookie is sleeping with her cat in her bedroom, the walls of which are pink with floral motifs. Her bedroom, combined with her outfit, aligns her with stereotypical girlish femininity and purity and the popular idea that "blue is for boys and pink for girls." She wakes up and looks through her window.

Figure 10: Bill waiting in front of Sookie's window [S01E01, 34:30]

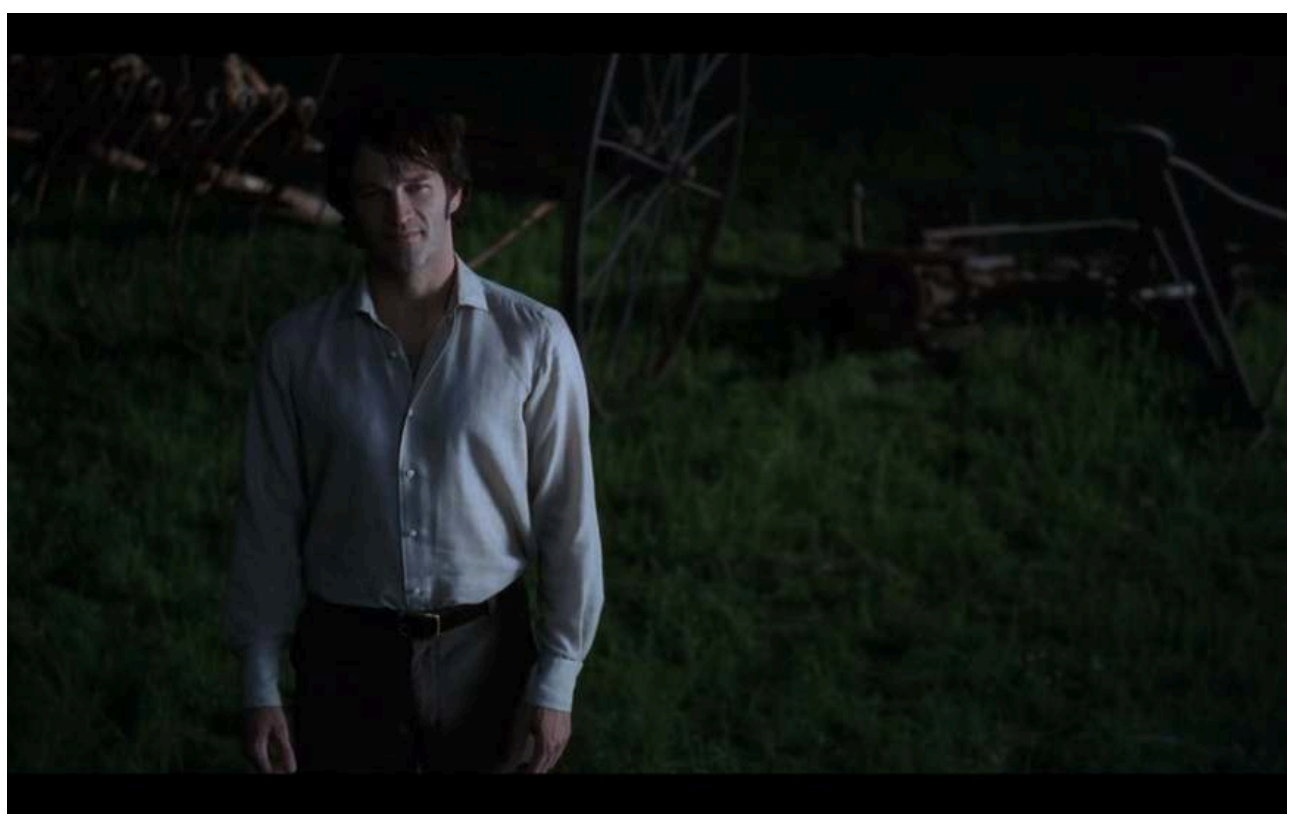

Bill is waiting at night in front of her bedroom's window, dressed in $19^{\text {th }}$ century fashion, with a loose white button-down shirt, gray pants, and standing in front of an old harvester (Fig.10). His position in front of the window reflects Sookie's expectations in terms of romanticism and summons up cultural history, being reminiscent of the genre of historical romance. This framing aligns him with the gallant southerner stereotype and reminds both Sookie and the viewers that he comes from another century, a Civil-War-era past that underpins the Southern narrative. Sookie's house's first appearance associates it with history but also sets it as the place where its owner's desires thrive. Such an association between a woman, a house, and history certainly grounds the series in classic Gothic fiction. Far from being a mere background to a reinterpretation of history and cultural history, Sookie's house triggers it. The house, unlike everyone or anything else in the series, thus has the power to unravel Sookie's appearance and, by extension, Southern cultural history. Sookie's dream foreshadows her development in the line of the Southern Belle. Unlike this stereotype, though, she belongs to the working-class, hence updating this stereotypical figure that came to represent an idealized version of the South with Scarlett O'Hara (Vivien Leigh) in Gone with the Wind (O'Selznick, 1939), before that in The Birth of a Nation and then later in A Streetcar Named Desire. In True Blood, the Belle does not necessarily come from a wealthy family but remains white and possesses a natural aristocracy as Sookie incarnates the virgin princess. Logically, then, the Belle is also the center of attention courted by faithful servants ${ }^{22}$.

34 The outside of her house is first seen when Sookie joins Bills outside. Its architecture is reminiscent of fourth generation Acadian homes. These Louisianan houses, home to Cajun families, are characterized by their galleries, gable roofs covered with wood 
shingles, wooden shutters and white wood ${ }^{23}$. The architectural style anchors the series in a Louisianan context which sets it apart from other Southern States and is propitious to the questioning of identities. Without uttering a word, Bill unbuttons his shirt and a POV medium close shot displays his hairy chest to the viewers, thus objectifying the male body for both Sookie and the viewers, a far cry from the traditional heterosexual male gaze. Then, Sookie slowly opens her robe and says "I never thought I would be having sex with you... At least, not so fast." This erotic dream, constructed as the beginning of a soft porn movie, conflates the two sensational motifs of the vampire and the southern belle, and draws on preconceived misconceptions about sexuality and exposes True Blood's reliance on the grotesque in its framing of sexual behaviors. The end of the sequence associates a close-up of Bill's protruding fangs with an extradiegetic sound that accentuates the dangerous position Sookie is in. Being her dream, it appears that she has internalized the danger associated with vampires to which other characters keep on referring, but also that the virgin belle fears exploring her sexuality. More than just being a humorous scene, Sookie's dream exacerbates the stereotypical representations of the southern historical romance genre's containment in the private sphere, here her house. In the end, it might be as lethal to replay the Southern romance as it would be to replay the South's past.

In S01E02, Bill is invited by Adele Stackhouse to talk about his upcoming speech in front of the Glorious Dead Society. When he gets there, Bill meets Tara (Rutina Wesley), Sookie's best friend, and Jason, Sookie's brother. During their conversation, Tara and Jason are seated on armchairs while Bill, Sookie, and Adele are on the couch in front of them. At the beginning of the scene, a pan goes from Jason and Tara to Bill and Sookie, as if it were a sports competition, the coffee table acting as a form of separation between both sides (Fig.11).

Figure 11: Long shot of Adele, Bill and Sookie (left) and Jason and Tara (right) [S01E02, 30:33]

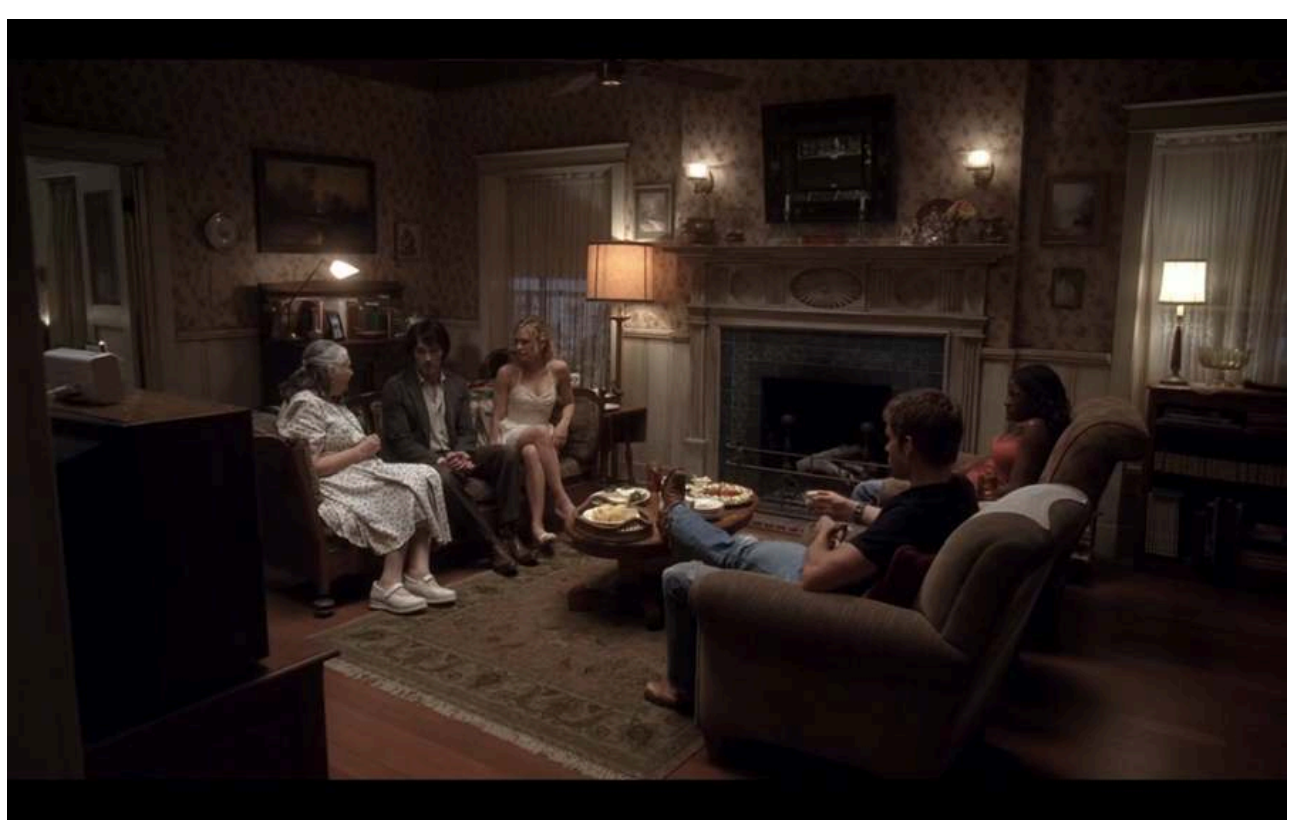

When Bill mentions the Vampire Rights Amendment, Jason shows his prejudice against vampires. He uses an argument that was frequently used by segregationists against African Americans during the Civil Rights Movement, and later by conservatives 
against homosexuals: "a lot of Americans don't think you people deserve special rights" [S01E02, 30:55-31:00], the expression "you people" furthering the vampire's unAmericanness, thus their construction as forms otherness. Unlike Jason, Tara, who is black, replaces Bill as part of the US and its history and confronts his apparent progressive stance when she asks him if he owned slaves in the past. Tara, whose name is that of the plantation in Gone with the Wind (Mitchell, 1936), is the one who points at the problematic question of the legacy of the plantation system in the South. In other words, the culturally emblematic plantation house gives way to a reflection on racial differences in the series. Interestingly, it is one of the rare moments where the series overtly addresses its post-racial view, hence highlighting the relevance of past differences induced by the geographical and cultural contexts. In addition to her not liking him because he is a vampire, this question reveals that her hostility is also based on Bill's past. She focuses on the racial hierarchy of the past. This is surprising, even more so as she does not voice her opinion against the implicit form of racism expressed by the members of the Glorious Dead Society, the aim of which is to rehabilitate soldiers who fought against the abolition of slavery. Not only is this hierarchy racial, but it also works on the level of social classes. Tara indeed supposes that Bill's family had the means to buy slaves. The vampire figure being originally associated with nobility, Bill represents a minority elite, that of rich vampires, and comes from a family of slaveowners. Bill's vampiric nature allows Tara to attack traditional hegemonic discourses since the black woman in power holds a wealthy, heterosexual white man accountable for his past actions. Tara mentioning the past allows us to draw a parallel between Classical Hollywood cinema, the film conventions of which the series reproduces, and the present. On the one hand, she exposes the fact that whites used to own slaves at the time of the Civil War. On the other, most of the characters in True Blood are white and keep on marginalizing minorities regardless of Louisiana's sociological makeup, Tara and Lafayette being the only recurring African-American characters and having secondary roles. The tensions occurring behind closed doors underline the house's importance in serial storytelling, but they also stress the house's embodiment of discourses related to both dominant and oppressed groups. The living room becomes a theatrical stage on which these discourses are replayed and reassessed, on which hegemonies are overacted and ridiculed. True Blood displays its politically committedness and shows, through its exploration of cultural history, that past gender, race, class and sexual hierarchies - even though they are denounced by the vampire metaphor - are still as divisive as ever.

Sookie's house is the last place to appear in the series' finale, in a long tracking shot showing most of the recurring characters of the True Blood universe gathered for a barbecue. More than adding new elements to the series, this final shot alludes to a reflection on how much these characters have evolved. The first character who is followed by the final long tracking shot is Jason, who now has three children and is playing with them before he joins everyone else at the table. This shot sums up his growth throughout the series. He went from being a player who goes from woman to woman to a fatherly figure, suggesting that a realignment of these stereotypes to fit into the traditional patriarchal scheme of the white, working-class nuclear family. The viewers get to see a pregnant Sookie kiss her husband, whose face remains unseen, meaning her happiness does not depend on him, or at least not on his identity. The only piece of information that can be deducted about him is that he is not a vampire, since vampires cannot procreate in the True Blood universe. What is surprising is that, 
throughout the series, Sookie had been looking for figures of otherness since she dated two vampires (Bill and Eric) and a werewolf (Alcide). Her being married shows that hegemonic discourses are so anchored in everyone's minds that even figures of otherness must submit to them to be happy: the Belle becomes a respectful spouse guarded by masculine authority. The same idea applies to Sam, the shapeshifter, who is married to another shapeshifter and has two children, hence reperforming the standards of the nuclear family within a minority group.

While these two figures of otherness are given a traditional ending, Arlene and her vampire boyfriend are at the table in the last sequence. Her brother-in-law, Andy Bellefleur, Bon Temps' Sheriff who had faerie quadruplets during the series, is also there with his daughters. In the series, Andy finds out that he is related to Bill Compton when he finds the Compton name in his family tree. The merging of the Compton and Bellefleur last names in history is induced by the series' Louisianan setting, Compton being Anglo-Saxon and Bellefleur French. This mixed cultural heritage recalls the different cultural influences present in Louisiana and reinforces the themes of collaboration and diversity within a small Southern community. Even though the Louisianan, here Cajun, identity attached to Andy's French last name is not really developed, this lineage is proof of what True Blood has shown from its very first sequence, that vampires and Southerners are not necessarily antithetical. Contrary to Sookie and Sam, Arlene and Andy used to stand for hegemonic discourses, but they have gradually changed their positions to be more in tune with people who represent figures of otherness.

Until the end of the series, Sookie's house allows the characters to reach a middle ground between tradition and progress. It is a place for otherness to merge with more traditional identities, just as Sookie's faerie identity merges with a more traditional working-class white woman's identity in the series finale (S07E10). The only character who does not have to comply is Lafayette. The black, gender-bending homosexual brujo ends up with a vampire boyfriend. As the only African-American character whose happy ending is indexed in taking his queerness to its limits, the character of Lafayette furthers the latent racial and sexual gap. The way for him to be happy is to push his queerness to its limits. In turn, the more traditional characters become more openminded by adapting their social structure to include blackness and queerness.

\section{A Past to Count On: Bill Compton's Plantation House}

Bill's house appears as the translated image of Sookie's, spatially incarnating the romantic narrative at the core of the first seasons. The antebellum house of a gallant southerner, Bill's Louisianan plantation house is tied to history and mostly shown in the dark since the vampire cannot walk in daylight (Fig. 12). Bill's house first onscreen appearance occurs after the vampire's first visit to Sookie's house. They walk through the cemetery that separates his house from hers, evoking a series of oppositions - male and female, rich and working-class, human and vampire, and life and death - and yet acting as a porous boundary between the characters and dichotomies. A series of pans following the two lovers punctuated with medium close ups of them talking in shot/ reverse shot allow the viewers to apprehend the space between these two places. This path from her house to his goes through a cemetery, and from the normalcy of humanity to the otherness of vampires. 
41 incarnating a state of in-betweenness. Being where past people are buried and still have a place in the present, this place triggers a conversation about Sookie's and Bill's respective pasts. It is in the merging together of past and present induced by the cemetery that Sookie's state of otherness is openly discussed and echoed by a flashback showing young Sookie's discovery of her powers and exclusion from her Southern family. Her state of otherness is confirmed by Bill's attempt to glamour her, a technique used by vampires to control humans, which does not work. The more time the characters spend in the cemetery, the more Sookie is empowered. Throughout the scene, she does not conform to the clichés of traditional courting and appears insistent while Bill is more reserved. The working-class woman is more in control than the wealthy man. Bill's restraint, in line with his traditional values, reinforces his characterization as a gallant southerner which collides with the evolution of social norms that has occurred since he lost his humanity. Thus, the cemetery's state of inbetweenness blurs historical and cultural boundaries in terms of identity. It turns social norms upside down and allows Sookie's humanity and Bill's otherness to be overtly questioned.

Bill's principles are contrasted with Sookie's modern values about dating and previous erotic dream about him. The first appearance of the house reinforces Bill's belonging to a more conservative past but also his will to adapt to his new reality. He is renovating it, just as he is attempting to adapt to contemporary behaviors. The house, just like the characters' identities, is a façade which combines the otherness associated with the vampire archetype on the one hand, and the marks of the segregationist past and of the South's traditional values on the other. A historically socially conservative place is home for the vampire other, thereby furthering the similarities between vampire and human norms and tying them to the past. The couple's standing in front of a visual representation of the South's past (Fig.12), because it visually echoes Sookie's dream, draws a parallel between romanced history and reality. In this scene, Sookie is not replaying Southern history as much as in her dream. On the contrary, her control of the situation de-mythifies Southern history which is, in turn, not repeated. Whereas the past expressed by this house is one of racial hegemony, as plantation houses were owned by wealthy white men, the old harvester Bill stood in front of in Sookie's dream aligned him with field workers. In a sense, the Stackhouses' is imbued with Southern cultural history while Bill's plantation house bears the marks of an abject Southern past. These characters' houses thus embody the tensions between history and cultural history, the cemetery standing between them physically incarnating and triggering an update of these pasts to contemporary standards. 
Figure 12: Long shot of Bill's plantation house [S01E02, 42:15]

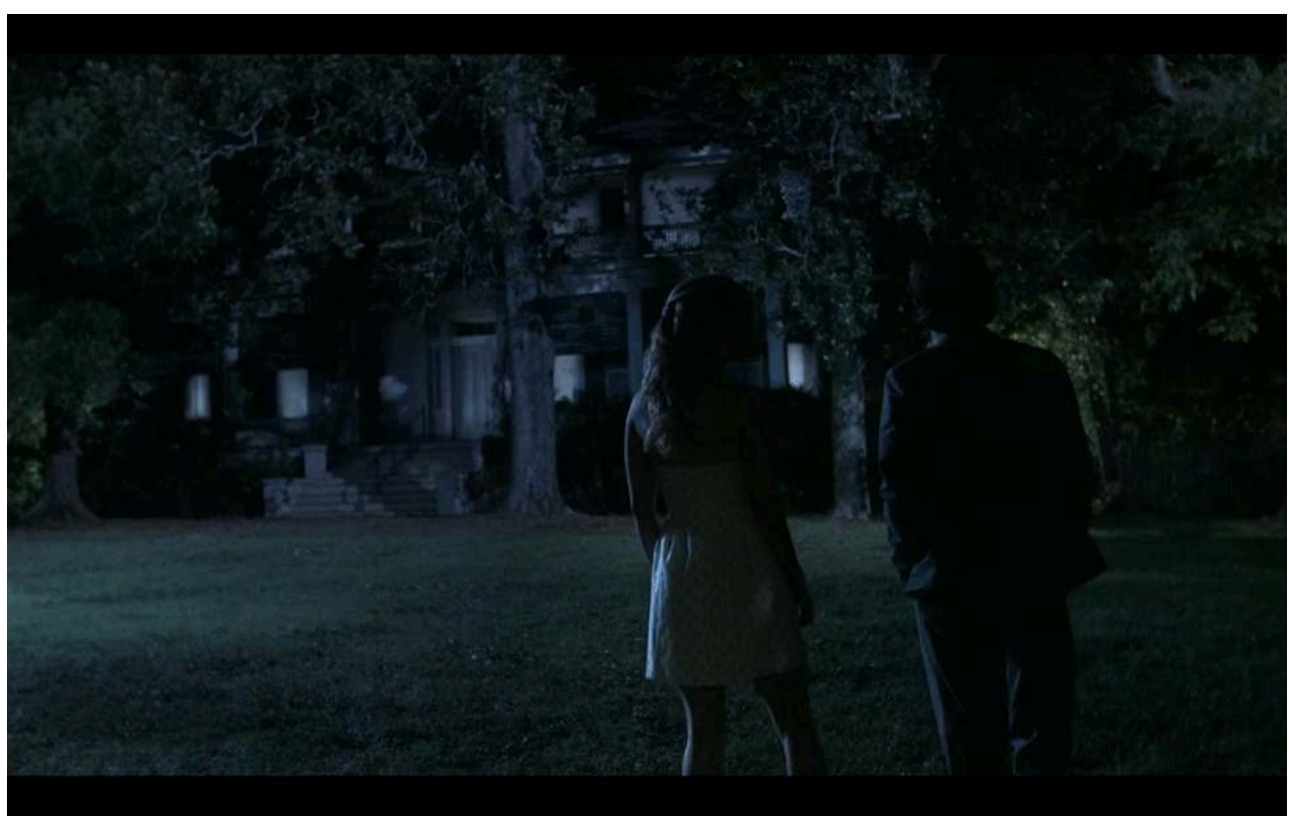

Bill's house is the place where Sookie loses her virginity in a sensual and romantic sequence mostly filmed in close-ups of Sookie's and Bill's faces edited in shot/reverse shot. Sookie is wearing a white nightgown, thus evoking purity in both the Gothic and Southern traditions. Fig $n^{\circ} 13$ shows the couple surrounded by fire, literalizing the undercutting passion. They are in front of the fireplace and several candles are lit all around them. The warm colors induced by these lights turn the deathly place into a safe haven. The romantic ideal, that is a subjection to traditional heteronormative discourse of the place of the man and of the woman in a couple, is put forward in a grotesque way. Bill's protruding fangs not-so-subtly echo his erection, and his biting her neck results in an effusion of blood which stands for Sookie's loss of her virginal purity. The house is the place where Sookie's sexual innocence is lost. It parallels Fangtasia's exploitation of sexual desires. Here, sexual desire is not commodified but rather included and contained in the romantic ideal of the first sexual experiences as part of a historical romance. The house and its interior design reinforce Bill's gallantry by framing him as a respectful southerner, but also anchors the couple in cultural history, since the gallant southerner is the one who, after he courts his Belle, can become more intimate with her. Bearing so much historical meaning, Bill's plantation house summons up cultural history and, just like Sookie's house, triggers a reenactment of the Southern, Gothic, soft porn tropes which, shown in a grotesque way, are ridiculed. 
Figure 13: Sookie about to lose her virginity to Bill, S01E06 [48:55]

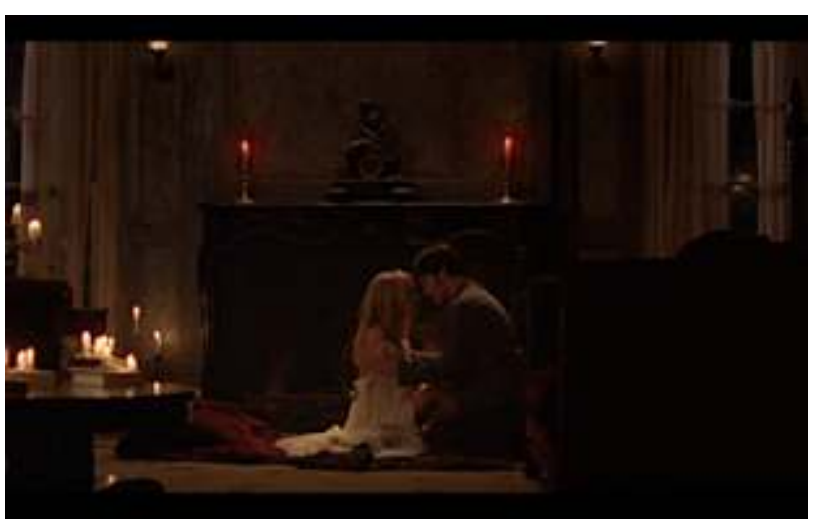

The ellipsis at the beginning of S04E01 is a source of renewal and implies that the characters have greatly evolved during Sookie's absence. Bill has become the Vampire King of Louisiana, which marks a complete shift in his character development as he takes on the legacy of the role of the plantation owner he rejected in the first seasons. In a nod to Dracula, Bill acts the part of the vampire aristocrat and tyrant when he becomes more violent and authoritarian and wants his subjects to obey his orders. This change of status is heightened by the change of decoration. From S04E01 on, the house's walls as well as its furniture look colder; they are black and white, and more modern. The house sheds its inner body as well as its past to fit with forthcoming dramatic tensions and adapt to vampire royalty which, in all its glory, replays the South's shameful past. The house becoming more modern visually echoes the similarities between vampire and human orders, showing that powerful forms of otherness are aligned with hegemonic groups. In the first season, this past is used to make a parallel between True Blood's vampires' quest for equal rights and what African Americans, LGBTQ+ and other oppressed communities have gone through in American history. Bill is replaying the past he so enthusiastically rejected in the first seasons shows that old human hegemonic discourses die hard, so much so that human and vampiric societies are based on the same values. Like Fangtasia, Bill's house incarnates a form of hegemonic otherness that is based on white, wealthy, heterosexual masculinity, thus reasserting the similarity between the norms holding in the vampire and human worlds. The historically conservative place frames Bill into replaying the past and appears as a synecdoche of the stereotypical view of the South the series is attempting to overtly qualify.

Bill's house however gives way to a more liberal discourse with the celebration of Jessica, Bill's vampire daughter, and Hoyt's, one of the rednecks who live in Bon Temps, union [S07E10, 26:56-38:38]. During their wedding ceremony, Bill is dying with Hep-V and Sookie can hear his thoughts for the first time. The plot gradually closes on itself since it is something Sookie would have liked to be able to do throughout the series. The union exacerbates the dichotomy between tradition and progress Bill's house is based on. On the one hand, it replays the patriarchal tradition of a wedding, with Bill walking his vampire daughter down the aisle and giving her away to a man and Sookie incarnating a motherly figure for Jessica as she is the one who helps her put on her bridal dress. This wedding is the first and only inter-species union openly displaying the series' social stance when Andy Bellefleur, acting as minister, states: "The State of Louisiana, the United States of America, may not recognize this union. But, for my 
money, there ain't a doubt in my mind that God does. The love you two share is beautiful, and love is love. Plain and simple" (Fig.14). This line reminds the viewers of the history of interracial unions and echoes the social debate, at the time, over samesex marriage. The last season of the series was released in 2014, a year after the Supreme Court decision on United States $v$. Windsor ${ }^{24}$ which recognized same-sex marriages at the Federal level even though the State of Louisiana maintained its ban. Once and for all, True Blood reaffirms its stance in its most conservative locus, even though it does not fundamentally upset the ideologies of the South.

Figure 14: True Blood's first and only inter-species union [S07E10, 36:33]

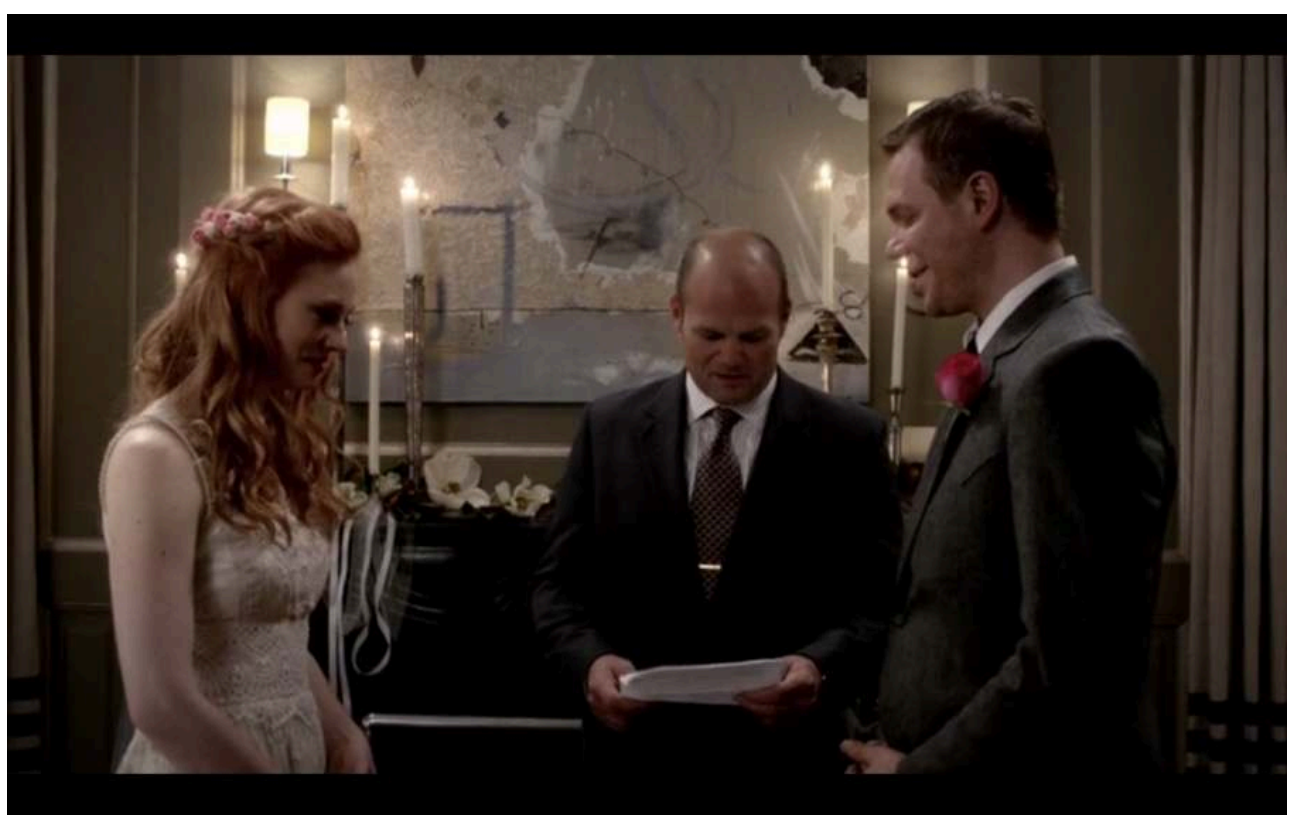

\section{Conclusion}

True Blood's four main places - the Southern swamp bar, the goth club, the plantation house and the Acadian house - echo one another and are sites in which the stereotypical white, heterosexual, working-class Southern identity is confronted to figures of otherness that underscore its weaknesses and limits. Their complementarity participates both in the series' politics and narrative. Not only are these places just spatial, but they are also gendered and racialized time-spaces where identities are played out and subverted. The identities sociologically present in Louisiana are hinted at by True Blood without really being developed. Rather, they are Americanized and included in a global version of what the South is believed to be regardless of Louisiana's sociological reality. Be it in Merlotte's or Fangtasia, these hegemonies are revealed as performances and thus undermined on the stages represented by the main rooms of these public places. What is at stake is not so much a subversion but rather a confrontation of different aspects of identity. Merlotte's is home to confrontations between a stereotypically Southern conservative clientele and figures of otherness. The dramatic tensions happening there allude to a reassertion of identities and the coexistence of both hegemonic and non-hegemonic in this place. The traditional Southern identity is confronted to figures of otherness in Merlotte's, which points at 
the power play at stake in terms of identity. On the contrary, Fangtasia resorts to a paradoxical hegemonic otherness; specist and sexual differences become the norm. Unlike True Blood's three other places, Fangtasia does not evolve much and ends where it began. It remains a place where vampire identity is commodified and vampiric capitalism exacerbated. The similarities between vampiric and human places show that vampires are more conservative than one would think, human hegemonic values being pervasive and powerful enough to live on after death.

These places are neither completely conservative nor liberal, and they are not completely conforming to hegemonic discourses nor fully embracing otherness. True Blood thus dramatizes the fissuring of what popular culture imagines Southern identity to be: conservative, traditional, rural, white, and heterosexual among others. Imbued with theatricality, Merlotte's and Fangtasia are the stages on which the deconstruction of this stereotypical identity is effected. Sookie's and Bill's houses do so through the development of the protagonists' personal relationships, even though the tension between public and private is palpable in each of the places under study because of the drama genre conventions underlying the narrative. The Stackhouses' house, where cultural history comes out as a strong dramatic tool, is inhabited by a progressive yet nostalgic grandmother, Adele, and a figure of otherness, Sookie. The conventional ending for the Sookie character, who is married and pregnant in the last scene, however shows that hegemonic traditions are also sought by figures of otherness. Bill's house first is a place where the South's traditional history is replayed. Yet it eventually becomes the place where the first (and only) inter-species wedding is officiated, thus home to progress within a traditional setting. These two private places find a balance between tradition and progress, and between hegemony and otherness. Opening in Merlotte's and closing in Sookie's house, the serial format induces a specific evolution for True Blood's places with an arc taking the viewers from a public space to a private space become public which fully integrates forms of otherness. In the series' final installment, the houses become home to a reconstruction of Southernness on a middle ground between tradition and progress. The Southerners shown at the end of the series are not as conservative and traditional as they used to be, the houses acting as dramatic stages on which the reconstruction of a less-stereotypical Southern identity is executed, even though it is still a white, working-class, heterosexual one.

Given True Blood's liberalism and promotion of otherness in its public places, Sookie's ending could be seen as a letdown. Yet the last sequence of the finale shows a diversified representation of the region that encapsulates the various experiences of Southerners. It is not the historical past itself that is disrupted in the series but rather the cultural one. The series' four main places are not defined by the characters' behaviors; rather, they frame and trigger them. The confrontation of stereotypical places alludes to a certain form of harmony between tradition and progress. The boundaries between these apparently dichotomous concepts are made more porous and allow, paradoxically, both otherness to thrive within patriarchal rules and patriarchal institutions to be reasserted by figures of otherness. It is thanks to that balance that the series can wrap up, the camera zooming out and fading out on the characters, whose adventures were followed for seven years, finally having a bon temps. [S07E10, 1:03:05] 
Figure 15: Last shot of the series [S07E10, 1:03:05]

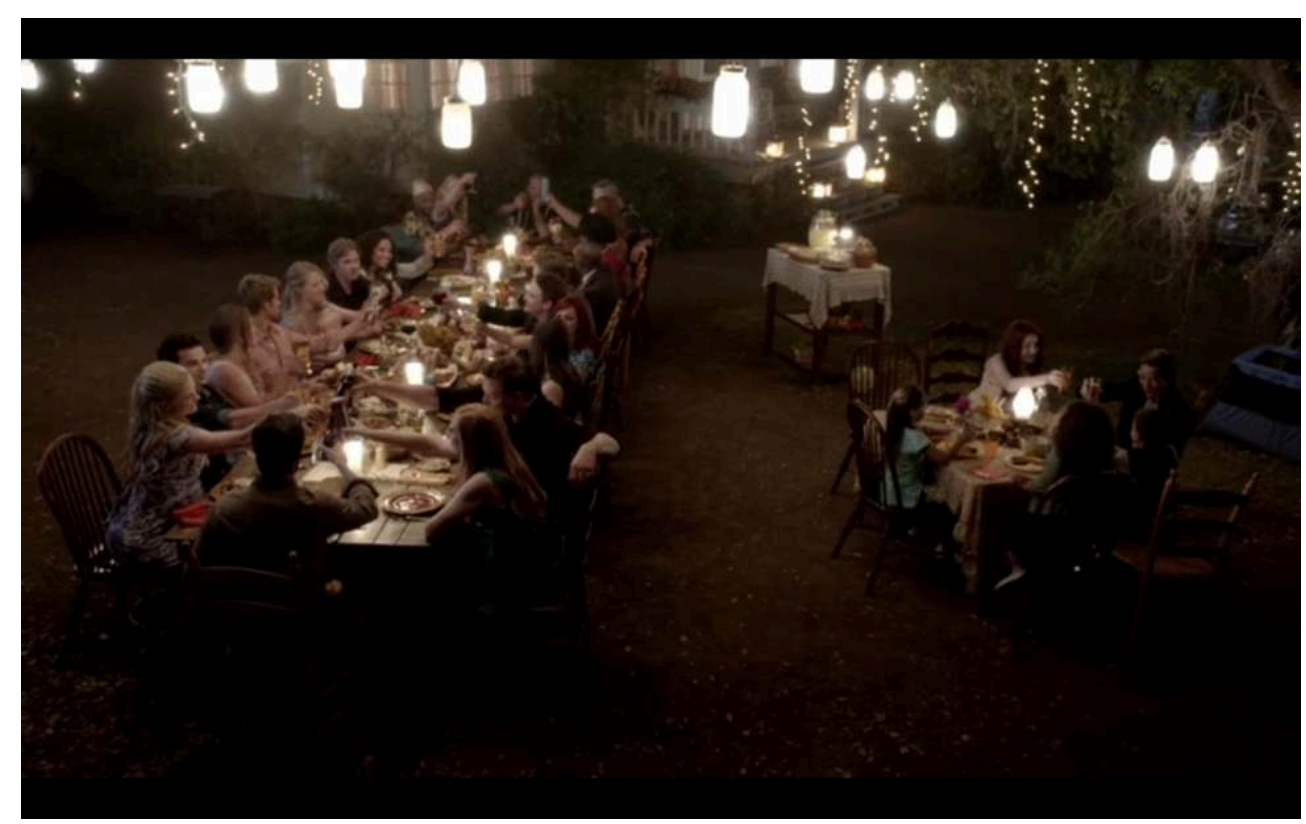

\section{BIBLIOGRAPHY}

ANCELET, Barry Jean, EDWARDS Jay D., PITRE, Glen, Cajun Country Folklife in the South Series, Jackson, University Press of Mississippi, 1991.

BOGLE, Donald, Toms, Coons, Mulattoes, Mammies \& Bucks, New York, Bloomsbury, 2001.

BOYER, Sabrina, "Thou Shalt Not Crave Thy Neighbor: True Blood, Abjection, and Otherness", Studies in Popular Culture, Vol. 33, No. 2, 2011, p. 21-41.

BURLEY, David M., Losing Ground: Identity and Land Loss in Coastal Louisiana, Jackson, University Press of Mississippi, 2010.

CHAMBERS, Samuel, The Queer Politics of Television, New York, Palgrave Macmillan, 2009.

CREED, Barbara, The Monstrous Feminine: Film, Feminism, Psychoanalysis, London, Routledge, 2007.

CRENSHAW, Kimberlé, “Mapping the Margins: Intersectionality, Identity Politics, and Violence Against Women of Color", Stanford Law Review, Vol. 43, No. 6, 1989, p. 1241-1299.

COBB, James C, Away Down South: A History of Southern Identity, New York, Oxford University Press, 2005.

EASTHOPE Anthony, What a Man's Gotta Do: The Masculine Myth in Popular Culture, New York, Routledge, 1990.

GODDU, Teresa A., Gothic America: Narrative, History and Nation, New York, Columbia University Press, 1997. 
GREVEN, David, "The Southern Gothic in Film: An Overview", in The Palgrave Handbook of the Southern Gothic, ed. Susan Castillo Street and Charles L. Crow, London, Palgrave Macmillan, 2016.

LANGMAN, Larry, EBNER, David (eds), Hollywood's Image of the South. A Century of Southern Films, Westport, Greenwood Press, 2001.

MASSEY, Doreen, Space, Place, and Gender, Minneapolis, University of Minnesota Press, 1994.

MENNEL, Barbara, Cities and Cinema, London and New York, Routledge, 2008.

MITTELL, Jason, Complex TV: The Poetics of Contemporary Television Storytelling, New York, New York University Press, 2015.

MULCAHY, Kevin V., Public Culture, Cultural Identity, Cultural Policy: Comparative Perspectives, New York, Palgrave Macmillan, 2017.

PUNTER, David, BYRON, Glennis, The Gothic, London, Blackwell, 2004.

SPOONER, Catherine, Fashioning Gothic Bodies, Manchester, Manchester University Press, 2004.

TRÉPANIER, Cécyle, “The Cajunization of French Louisiana: Forging a Regional Identity” The

Geographical Journal. Vol. 157, No. 2, July 1991, p. 161-171.

TUHKUNEN, Taïna, Demain sera un autre jour : Le sud et ses hérö̈nes à l'écran, Pertuis, Rouge Profond, 2013.

\section{NOTES}

1. David Greven, "The Southern Gothic in Film: An Overview", The Palgrave Handbook of the Southern Gothic, ed. Susan Castillo Street and Charles L. Crow, London, Palgrave Macmillan, 2016, p. 474.

2. Teresa A. Goddu, Gothic America: Narrative, History and Nation, New York, Columbia University Press, 1997, p. 82.

3. Taïna Tuhkunen, Demain sera un autre jour : le Sud et ses héroïnes à l'écran, Pertuis, Rouge Profond, 2013, p. 19.

4. Jason Mittell, Complex TV: The Poetics of Contemporary Television Storytelling, New York, New York University Press, 2015, p. 263.

5. Mittell, p. 22.

6. Mittell, p. 269.

7. Mittell, p. 261-291.

8. Mittell, p. 261.

9. Doreen Massey, Space, Place, and Gender, Minneapolis, University of Minnesota Press, 1994, p. 1.

10. Massey, p. 2.

11. Massey, p. 5.

12. Massey, p. 10.

13. Kimberlé Crenshaw, "Mapping the Margins: Intersectionality, Identity Politics, and Violence Against Women of Color", Stanford Law Review, Vol. 43, No. 6, 1989, p. 1244.

14. David M. Burley, Losing Ground: Identity and Land Loss in Coastal Louisiana, Jackson, University Press of Mississippi, 2010, p. 40.

15. Mittell, p. 325.

16. Mittell, p. 323.

17. Sabrina Boyer, "Thou Shalt Not Crave Thy Neighbor: True Blood, Abjection, and Otherness", Studies in Popular Culture, Vol. 33, No. 2, 2011, p. 39.

18. Samuel Chambers, The Queer Politics of Television, New York, Palgrave Macmillan, 2009, p. 56. 
19. Donald Bogle, Toms, Coons, Mulattoes, Mammies \& Bucks, New York, Bloomsbury, 2001, p. 13-14.

20. Barbara Creed, The Monstrous Feminine: Film, Feminism, Psychoanalysis, London, Routledge, 2007, p. 17.

21. Creed, p. 19.

22. Ibid.

23. Barry Jean Ancelet, Jay D. Edwards, and Glen Pitre, Cajun Country Folklife in the South Series, Jackson, University Press of Mississippi, p. 129-136.

24. The Supreme Court ruled that section 3 of the Defense of Marriage Act, passed by the Clinton administration, which stated that same-sex marriages could not be recognized by the Federal State, was a violation of the Fifth Amendment to the US Constitution.

\section{ABSTRACTS}

HBO's series True Blood (Alan Ball, 2008-2014) explores a storyworld in which vampires have come out of the coffin and live openly among humans, thus confronting hegemonic discourses with figures of otherness. This chapter focuses on the dramatic and political potential of the series' places. Be they public (Merlotte's, the Fangtasia) or private (Sookie's house, Bill's mansion), they participate in True Blood's seriality by bringing viewers back to familiar places where identities are played out and subverted. For instance, Merlotte's, the stereotypical southern diner, is where the stereotypical version of Southernness is confronted to figures of otherness. Its vampire counterpart Fangtasia embraces otherness and non-normative fantasies only to commodify them by integrating them into a capitalist structure. The four recurring places of the series are sites in which normative and non-normative behaviors compete and are contained. As central stages, these places, where most of True Blood's moments of tension and reconciliation occur, partake in the series' narrative and political complexity and in a reevaluation of the legacy of Southern history and cultural history.

La série True Blood (2008-2014), créée par Alan Ball et diffusée par HBO explore un monde où les vampires sont sortis du cercueil et vivent ouvertement avec les humains, confrontant ainsi les discours hégémoniques à des formes d'altérité. Ce chapitre s'intéresse aux quatre lieux récurrents de la série : le bar et grill Merlotte's, la boîte de nuit Fangtasia et les maisons de l'héroïne Sookie Stackhouse et de son amant vampirique Bill Compton. Nous verrons ils participent à la sérialité de True Blood en ramenant les spectateurs dans des lieux familiers où les identités sont jouées et subverties. À titre d'exemple, au Merlotte's, stéréotype du bar rural du Sud états-unien, l'identité sudiste telle que popularisée dans les films et séries est confrontée à des formes d'altérité. Son équivalent vampirique, le Fangtasia, n'embrasse l'altérité et les fantasmes non-normatifs que pour les commodifier en les intégrant dans une structure capitaliste. Les lieux étudiés dans ce chapitre, qu'ils soient publics ou privés, sont des sites dans lesquels des comportements normatifs et non-normatifs s'opposent et sont contenus. C'est en leur sein que les moments de tension et de réconciliation de la série se jouent. Ils participent ainsi à la complexité politique et narrative de la série et permettent une réévaluation de l'héritage de l'histoire et de l'histoire culturelle sudiste. 
INDEX

Mots-clés: True Blood, Louisiane, intersectionnalité, politiques identitaires, espace, lieux

Keywords: True Blood, Louisiana, intersectionality, identity politics, space, place

\section{AUTHOR}

\section{MIKAËL TOULZA}

Mikaël Toulza est doctorant à l'université Toulouse Jean Jaurès. En adoptant une approche intersectionnelle, sa thèse interroge les implications politiques des représentations du vaudou louisianais dans les fictions audiovisuelles américaines.

Mikaël Toulza is a PhD candidate at the University of Toulouse Jean Jaurès, France. His dissertation seeks to interrogate the political implications of the representation of Louisiana voodoo in American cinema and television through an intersectional approach. 